\title{
RECIPROCAL MODULATION OF AGONIST AND ANTAGONIST BINDING TO INHIBITORY ADENOSINE RECEPTORS BY 5'- GUANYLYLIMIDODIPHOSPHATE AND MONOVALENT CATIONS ${ }^{1}$
}

\author{
RICHARD D. GREEN
}

Department of Pharmacology, University of Illinois at Chicago, College of Medicine, Chicago, Illinois 60612

Received October 27, 1983; Revised March 23, 1984; Accepted March 29, 1984

\begin{abstract}
Previous work from this laboratory showed that rat hippocampal membranes contain adenosine receptors that mediate GTP-dependent inhibition of adenylate cyclase activity (Yeung, S. -M. H., and R. D. Green (1983) J. Biol. Chem. 258: 2334-2339). Furthermore, we reported that guanine nucleotides decrease agonist and increase antagonist binding to these adenosine receptors. 'The present study examines the effects of monovalent cations and guanine nucleotides, alone and in combination, on the binding of agonist $\left(\left[{ }^{3} \mathrm{H}\right] N^{6}(\mathrm{~L}\right.$-phenylisopropyl)adenosine) and antagonist ( $\left[{ }^{3} \mathrm{H}\right]$ diethylphenylxanthine) radioligands to adenosine receptors in rat hippocampal membranes. Low concentrations of monovalent cations ( $\leqslant 100 \mathrm{mM})$ did not affect agonist binding. $5^{\prime}$ Guanylylimidodiphosphate $(\mathrm{Gpp}(\mathrm{NH}) \mathrm{p})$ alone increased the $K_{D}$ of the agonist without affecting the maximal number of sites labeled by the agonist $\left(B_{\max }\right)$; in the presence of monovalent cations, $\mathrm{Gpp}(\mathrm{NH}) \mathrm{p}$ both increased the $K_{D}$ and decreased the number of sites labeled by the agonist. In contradistinction, $\mathrm{Gpp}(\mathrm{NH}) \mathrm{p}$ increased the maximal number of sites to which the antagonist bound without affecting its $K_{D}$, while monovalent cations decreased the $K_{D}$ of the antagonist both in the absence and the presence of $\mathrm{Gpp}(\mathrm{NH}) \mathrm{p}$. It is proposed that both agonist and antagonist-receptor complexes exist in three distinct affinity states and that the transitions between these states are modulated by guanine nucleotides and monovalent cations. The results are consistent with a model in which the agonist radioligand measures binding to high and middle agonist affinity states of the receptor but does not measure hinding to a low agonist affinity state, while the antagonist radioligand measures binding to the middle and low agonist affinity states but not binding to the high agonist affinity state. According to this model the receptor exists in high agonist-low antagonist and high antagonist-low agonist affinity states and a third state with intermediate affinities for both agonists and antagonists.
\end{abstract}

Binding of radioligands to receptors coupled to adenylate cyclase has been widely studied. It is now clear that guanine nucleotides decrease agonist binding to receptors that mediate the inhibition (negatively coupled receptors) as well as those that mediate the stimulation (positively coupled receptors) of adenylate cyclase activity (Limbird, 1981; Cooper, 1982). Negatively coupled receptors seem to differ from positively coupled receptors in that antagonist binding to positively coupled receptors is, in general, unaffected by guanine nucleotides, while antagonist binding to negatively coupled receptors is increased by guanine nucleotides. This latter effect has been demonstrated for muscarinic cholinergic (Burgisser et al., 1982; Hosey, 1982), D-2-dopaminergic (DeLean et al., 1982), $\alpha_{2}$-adrenergic (U'Prichard et al., 1982; Woodcock and Murley, 1982), and $\mathrm{R}_{\mathrm{i}}$ adenosine receptors (Yeung and Green, 1983). In addition, monovalent cations have marked effects on ligand binding to negatively coupled receptors that are not apparent with positively coupled receptors (Limbird, 1981; Cooper, 1982). We recently reported that the $R_{i}$ adenosine receptor agonist $\left[{ }^{3} \mathrm{H}\right]-$

I thank S. -M. H. Yeung and M. M. Hosey for valued discussions during the course of this work and M. M. Hosey for critically reading this manuscript.
$N^{6}$-cyclohexyladenosine $\left(\left[{ }^{3} \mathrm{H}\right] \mathrm{CHA}\right)$ binds to $\mathrm{R}_{\mathrm{i}}$ adenosine receptors in rat hippocampal membranes with three distinct affinities depending on the assay conditions (Yeung and Green, 1983). High agonist affinity binding occurs in the absence of exogenous guanine nucleotide; the addition of $100 \mu \mathrm{M} 5^{\prime}$-guanylylimidodiphosphate $(\mathrm{Gpp}(\mathrm{NH}) \mathrm{p})$ increases the $K_{D}$ and decreases the $B_{\max }$ of $\left[{ }^{3} \mathrm{H}\right] \mathrm{CHA}$. Data were presented which suggested that, in the presence of $\operatorname{Gpp}(\mathrm{NH}) \mathrm{p},\left[{ }^{3} \mathrm{H}\right] \mathrm{CHA}$ binds to two different states of the $R_{i}$ adenosine receptor, a middle affinity state which is measured directly with $\left[{ }^{3} \mathrm{H}\right] \mathrm{CHA}$ and a low agonist affinity state which can be measured from $\mathrm{CHA}$ / $\left[{ }^{3} \mathrm{H}\right]$ diethylphenylxanthine $\left(\left[{ }^{3} \mathrm{H}\right] \mathrm{DPX}\right.$, an antagonist) competition curves. In addition, we reported that $\mathrm{Gpp}(\mathrm{NH}) \mathrm{p}$ increases $\left[{ }^{3} \mathrm{H}\right] \mathrm{DPX}$ binding to $\mathrm{R}_{\mathrm{i}}$ receptors. Goodman et al. (1982) reported somewhat similar studies on membranes from guinea pig brain and bovine forebrain. In contrast to our results, these workers reported that guanine nucleotides increase the $K_{D}$ of $\left[{ }^{3} \mathrm{H}\right] \mathrm{CHA}$ without affecting the $B_{\max }$ and that guanine nucleotides are without effect on the binding of $\left[{ }^{3} \mathrm{H}\right] \mathrm{DPX}$. A potentially important difference between our studies and those of Goodman et al. (1982) is that our incubations contained approximately $50 \mathrm{mM} \mathrm{NaCl}$ (added in the glycylglycine buffer used), while, unless specifically added, the incubations of Goodman et al. (1982) were devoid of monovalent cations. The 
studies presented in this communication characterize the interactions between monovalent cations and $\mathrm{Gpp}(\mathrm{NH}) \mathrm{p}$ on $\left[{ }^{3} \mathrm{H}\right]$ $N^{6}$ (L-phenylisopropyl)adenosine $\left(\left[{ }^{3} \mathrm{H}\right]-\mathrm{L}-\mathrm{PIA}\right.$, an agonist) and $\left[{ }^{3} \mathrm{H}\right.$ ]DPX binding to $\mathrm{R}_{\mathrm{i}}$ receptors in hippocampal membranes. These experiments were performed with $\left.{ }^{3} \mathrm{H}\right]$-L-PIA rather than $\left[{ }^{3} \mathrm{H}\right] \mathrm{CHA}$ because of the higher specific activity of the $\left[{ }^{3} \mathrm{H}\right]-\mathrm{L}$-PIA that is available. Limited experiments with $\left[{ }^{3} \mathrm{H}\right]$ CHA (results not given) gave results identical to those reported. The results of these studies apparently resolve some of the differences between results we previously reported (Yeung and Green, 1983) and data reported by Goodman et al. (1982) and, more importantly, give further insight into the modulation of ligand binding to $\mathrm{R}_{\mathrm{i}}$ adenosine receptors by guanine nucleotides and monovalent cations.

\section{Materials and Methods}

Materials. $\left[{ }^{3} \mathrm{H}\right]$-L-PIA $(49.9 \mathrm{Ci} / \mathrm{mmol})$ and $\left[{ }^{3} \mathrm{H}\right] \mathrm{DPX}(13.4 \mathrm{Ci} / \mathrm{mmol})$ were purchased from New England Nuclear. Sources of other drugs and chemicals were the same as previously detailed (Yeung and Green, 1983).

Preparations of membranes. Sprague-Dawley rats $(150$ to $350 \mathrm{gm}$, either sex) were killed by decapitation, and the hippocampi were rapidly dissected. Hippocampi were either processed immediately or stored intact in liquid nitrogen for later use. Hippocampal membranes were prepared by the method previously employed (Yeung and Green, 1983) with the exception that the hippocampi were homogenized in $10 \mathrm{mM}$ L-histidine/1 mM EDTA, $\mathrm{pH} \mathrm{7.5,} \mathrm{and} \mathrm{the} \mathrm{initial} \mathrm{centrifugation} \mathrm{was} \mathrm{at}$ $12,000 \times g$ for $10 \mathrm{~min}$. The membranes were resuspended in the histidine/EDTA buffer for study.

Ligand-binding assays. Incubation mixtures $(100 \mu \mathrm{l})$ contained $30 \mu \mathrm{l}$ of membrane preparation ( 150 to $250 \mu \mathrm{g}$ of protein), $10 \mathrm{mM}$ L-histidine (in addition to that added in the membrane preparation), $4 \mathrm{mM} \mathrm{MgCl}_{2}$, 2.5 units $/ \mathrm{ml}$ of adenosine deaminase, ${ }^{3} \mathrm{H}$-ligand, and other additions as noted. Incubations were performed in duplicate or triplicate at $37^{\circ} \mathrm{C}$ for $15 \mathrm{~min}$, at which time $3 \mathrm{ml}$ of ice-cold wash buffer (1 mM glycylglycine, $\mathrm{pH} 7.5,1 \mathrm{mM} \mathrm{MgCl}_{2}$ ) were added, and the sample was rapidly poured onto a Whatman GF/A filter under reduced pressure and washed three times with $4-\mathrm{ml}$ volumes of the same buffer. Samples conlaining 0.1 InM L-PIA were used to correct for nonspecific binding. Scatchard plots of $\left[{ }^{3} \mathrm{H}\right]-\mathrm{L}-\mathrm{PIA}$ binding were constructed using a single concentration of $\left[{ }^{3} \mathrm{H}\right]-\mathrm{L}$-PIA and varying concentrations of cold L-PIA. Parameters determined with this protocol gave values indistinguishable from those determined using varying concentrations of radiolabeled ligand. Scatchard plots of $\left[{ }^{3} \mathrm{H}\right] \mathrm{DPX}$ binding were constructed from experiments in which the concentrations of radioligand were varied. Parameters were determined by least squares analysis; $B_{\max }$ values are expressed in terms of milligrams of protein. Protein was determined by the method of Lowry et al. (1951).

\section{Results}

The effects of $\mathrm{NaCl}, \mathrm{KCl}$, and $\mathrm{NH}_{4} \mathrm{Cl}$ on the binding of $\left[{ }^{3} \mathrm{H}\right]$ -L-PIA to hippocampal membranes in the absence and the presence of $100 \mu \mathrm{M} \mathrm{Gpp(NH)p} \mathrm{were} \mathrm{determined} \mathrm{(Fig.} \mathrm{1).} \mathrm{(Con-}$ centrations of $\mathrm{Gpp}(\mathrm{NH}) \mathrm{p}$ between 0.1 and $100 \mu \mathrm{M}$ produce dose-dependent decreases in agonist radioligand binding to $R_{\mathrm{i}}$ adenosine receptors both in the absence (Goodman et al., 1982) and presence (S. - M. H. Yeung and R. D. Green, unpublished observations) of monovalent cations. $\mathrm{Gpp}(\mathrm{NH}) \mathrm{p}, 100 \mu \mathrm{M}$, produces a near maximal, if not maximal, effect and was used in all of the studies reported herein.) Fifty and $100 \mathrm{mM}$ concentrations of the monovalent cations had negligible effects on the binding in the absence of $\mathrm{Gpp}(\mathrm{NH}) \mathrm{p}$ (Fig. 1, solid lines) but significantly decreased binding when $\mathrm{Gpp}(\mathrm{NH}) \mathrm{p}$ was present (Fig. 1, dashed lines). Four hundred millimolar concentrations of $\mathrm{NaCl}$ and $\mathrm{NH}_{4} \mathrm{Cl}$ decreased the binding both in the absence and the presence of $\mathrm{Gpp}(\mathrm{NH}) \mathrm{p}$. While $400 \mathrm{mM} \mathrm{KCl}$ marginally affected binding in the absence of $\mathrm{Gpp}(\mathrm{NH}) \mathrm{p}$, it greatly depressed binding when $\mathrm{Gpp}(\mathrm{NH}) \mathrm{p}$ was present. $\mathrm{NH}_{4} \mathrm{Cl}$ appeared to be more potent than $\mathrm{NaCl}$ and $\mathrm{KCl}$ both in the absence and presence of $\mathrm{Gpp}(\mathrm{NH}) \mathrm{p}$.

Figure 2 summarizes an experiment in which the binding of

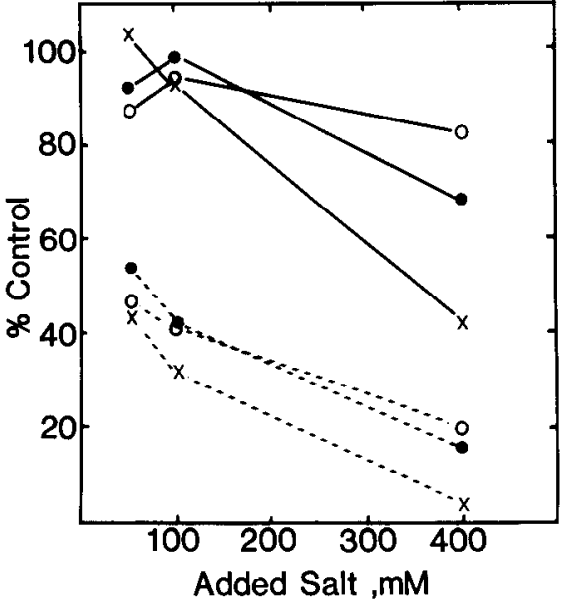

Figure 1. Effects of $\mathrm{NaCl}(\bullet), \mathrm{KCl}(\mathrm{O})$, and $\mathrm{NH}_{4} \mathrm{Cl}(X)$ on $\left[{ }^{3} \mathrm{H}\right]-\mathrm{L}$ PIA binding to hippocampal membranes in the absence (-) and presence (- - $)$ of $\mathrm{Gpp}(\mathrm{NH}) \mathrm{p}(100 \mu \mathrm{M})$. The points shown are the means of triplicate determinations. Data are expressed as percentages of the $\pm \mathrm{Gpp}(\mathrm{NH}) \mathrm{p}$ control values. Membranes were incubated with 2 nM $\left[{ }^{3} \mathrm{H}\right]-\mathrm{L}-\mathrm{PIA}(-\mathrm{Gpp}(\mathrm{NH}) \mathrm{p})$ or $10 \mathrm{nM}\left[{ }^{3} \mathrm{H}\right]-\mathrm{L}-\mathrm{PIA}(+\mathrm{Gpp}(\mathrm{NH}) \mathrm{p})$. The control values were 340 and $181 \mathrm{fmol} / \mathrm{mg}$ of protein, respectively.

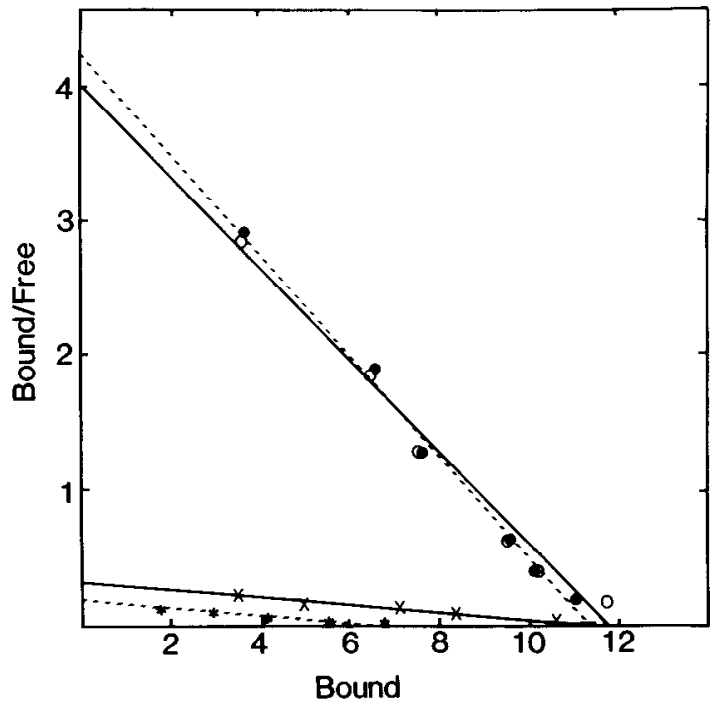

Figure 2. Scalchard plots of $\left[{ }^{3} \mathrm{H}\right]$-L-PIA binding determined simultaneously under four different conditions: (1) control (O-O), (2) 100 $\mathrm{mm} \mathrm{NaCl}(0-$ - ), (3) $100 \mu \mathrm{M} \mathrm{Gpp}(\mathrm{NH}) \mathrm{p}(\mathrm{X}-\mathrm{X})$, and (4) $100 \mathrm{~mm}$ $\mathrm{NaCl}+100 \mu \mathrm{M} \mathrm{Gpp}(\mathrm{NH}) \mathrm{p}\left({ }^{*}---^{*}\right)$. Samples were assayed in duplicate. Ordinate, Bound/Free (picomoles per sample.M) $\times 10^{-7}$. Abscissa, Bound picomoles per sample $\times 10^{2}$. The parameter estimates were as follows: $K_{D}$, nanomolar; $B_{\max }$ (femtomoles per milligram of protein): control, 4.2 (783); $\mathrm{NaCl}, 2.6$ (752); $\mathrm{Gpp}(\mathrm{NH}) \mathrm{p}, 34.9$ (752); and $\mathrm{NaCl}+$ Gpp(NH)p, 48.4 (519).

varying concentrations $\left[{ }^{3} \mathrm{H}\right]$-L-PIA was determined under four conditions: (1) control, (2) $100 \mathrm{mM} \mathrm{NaCl}$, (3) $100 \mu \mathrm{M}$ $\mathrm{Gpp}(\mathrm{NH}) \mathrm{p}$, and (4) $100 \mathrm{mM} \mathrm{NaCl}+100 \mu \mathrm{M} \mathrm{Gpp}(\mathrm{N}) \mathrm{p}$. The results of this and two other similar experiments are summarized in Table I. It is important to note that the effect of $\operatorname{Gpp}(\mathrm{NH}) \mathrm{p}$ to increase the $K_{D}$ of L-PIA was the same in the absence and presence of $\mathrm{NaCl}$, while the effect to decrease the $B_{\max }$ was markedly increased, if not dependent on, the presence of $\mathrm{NaCl}$. Under the conditions of these experiments $\mathrm{NaCl}(100$ $\mathrm{mM}$ ) alone did not have a significant effect on the binding of $\left[{ }^{3} \mathrm{H}\right]-\mathrm{L}$-PIA. Scatchard analyses of $\left[{ }^{3} \mathrm{H}\right]-\mathrm{L}$-PIA binding in the presence of higher concentrations of $\mathrm{NaCl}$ and $\mathrm{NH}_{4} \mathrm{Cl}$ but in the absence of $\mathrm{Gpp}(\mathrm{NH}) \mathrm{p}$ were also performed (Fig. 3). Under 
these conditions the monovalent cations (200 to $800 \mathrm{mM}$ ) caused dose-dependent increases in the $K_{D}$ of L-PIA and decreases in the numbers of sites to which the agonist radioligand bound. $\mathrm{NH}_{4} \mathrm{Cl}$ was more potent than $\mathrm{NaCl}$ (see the legend to Fig. 3 for parameter estimates).

The effects of $\mathrm{NaCl}$ and $\mathrm{NH}_{4} \mathrm{Cl}$ on the binding of the antagonist $\left[{ }^{3} \mathrm{H}\right] \mathrm{DPX}$ to hippocampal membranes were determined in the absence (Fig. 4, solid lines) and presence (Fig. 4, dotted lines) of $100 \mu \mathrm{M} G p p(\mathrm{NH}) \mathrm{p} . \mathrm{Gpp}(\mathrm{NH}) \mathrm{p}$ alone increased the binding of $\left[{ }^{3} \mathrm{H}\right] \mathrm{DPX}$. $\mathrm{NaCl}$, at 50 and $100 \mathrm{mM}$, did not affect the $\left[{ }^{3} \mathrm{H}\right] \mathrm{DPX}$ binding in the absence or presence of $\mathrm{Gpp}(\mathrm{NH}) \mathrm{p}$; however, these same concentrations of $\mathrm{NH}_{4} \mathrm{Cl}$ increased the binding of $\left[{ }^{3} \mathrm{H}\right] \mathrm{DPX}$ both in the absence and presence of $\operatorname{Gpp}(\mathrm{NH})$. Four hundred millimolar concentrations of both salts increased the binding of $\left[{ }^{3} \mathrm{H}\right] \mathrm{DPX}$ in both the absence and the presence of $\mathrm{Gpp}(\mathrm{NH}) \mathrm{p}$. The effects of $400 \mathrm{mM} \mathrm{NH} \mathrm{NH}_{4} \mathrm{Cl}$, $100 \mu \mathrm{M} \operatorname{Gpp}(\mathrm{NH}) \mathrm{p}$, and the combination of $\mathrm{NH}_{4} \mathrm{Cl}$ and $\mathrm{Gpp}(\mathrm{NH}) \mathrm{p}$ on Scatchard plots of $\left[{ }^{3} \mathrm{H}\right] \mathrm{DPX}$ binding were determined (Fig. 5A). The results from four similar experiments are summarized in Table II. Four hundred millimolar $\mathrm{NH}_{4} \mathrm{Cl}$ decreased the $K_{D}$ of $\left[{ }^{3} \mathrm{H}\right] \mathrm{DPX}$ both in the absence and the presence of $\mathrm{Gpp}(\mathrm{NH}) \mathrm{p} . \mathrm{NH}_{4} \mathrm{Cl}$ did not appear to affect the $B_{\max }$ determined under either of these conditions. On the other hand, $\mathrm{Gpp}(\mathrm{NH}) \mathrm{p}$ appeared to increase the $B_{\max }$ both in the absence and the presence of $\mathrm{NH}_{4} \mathrm{Cl}$. We had previously reported that $\left[{ }^{3} \mathrm{H}\right] \mathrm{DPX}$ binding to hippocampal membranes was increased by $N$-ethylmaleimide (NEM) pretreatment and that $\mathrm{Gpp}(\mathrm{NH}) \mathrm{p}$

\section{TABLE I}

Effect of $\mathrm{NaCl}(100 \mathrm{mM})$ and $\mathrm{Gpp}(\mathrm{NH}) \mathrm{p}(100 \mu \mathrm{M})$ on the binding of

\begin{tabular}{lcc}
\multicolumn{3}{c}{$\left[{ }^{3} H\right] P I A$ to hippocampal membranes } \\
\hline \multicolumn{1}{c}{ Group } & $K_{D}$ & $B_{\max }$ \\
\hline & $n M$ & fmol/mg of protein \\
Control & $3.0 \pm 0.6$ & $787 \pm 11$ \\
$\mathrm{NaCl}$ & $2.3 \pm 0.2$ & $762 \pm 18$ \\
$\mathrm{Gpp}(\mathrm{NH}) \mathrm{p}$ & $33.7 \pm 0.8$ & $680 \pm 45$ \\
$\mathrm{NaCl}, \mathrm{Gpp}(\mathrm{NH}) \mathrm{p}$ & $42.6 \pm 5.1$ & $432 \pm 55$ \\
\hline
\end{tabular}

${ }^{a}$ All values are means $\pm \mathrm{SE} ; N=3$. was without effect on $\left[{ }^{3} \mathrm{H}\right] \mathrm{DPX}$ binding to NEM-pretreated preparations. In the present experiments we also determined the effect of $\mathrm{NH}_{4} \mathrm{Cl}$ on $\left[{ }^{3} \mathrm{H}\right] \mathrm{DPX}$ binding to NEM-pretreated hippocampal membranes (Fig. 5B, Table II). The effects of $\mathrm{NH}_{4} \mathrm{Cl}$ on $\left[{ }^{3} \mathrm{H}\right] \mathrm{DPX}$ binding were qualitatively similar in control and NEM-pretreated preparations, i.e., $\mathrm{NH}_{4} \mathrm{Cl}$ decreased the $K_{D}$ without affecting the $B_{\max }$ in both cases.

\section{Discussion}

This report shows that both guanine nucleotides and monovalent cations reciprocally regulate the affinities of agonists and antagonists for $R_{i}$ receptors in rat hippocampal membranes. Results are presented that show that $\operatorname{Gpp}(\mathrm{NH}) \mathrm{p}$ increases the $K_{D}$ of L-PIA in the absence and the presence of 100 $\mathrm{mM} \mathrm{NaCl}$. However, the effect of $\mathrm{Gpp}(\mathrm{NH}) \mathrm{p}$ to decrease the $B_{\max }$ of L-PIA is enhanced if not dependent on the presence of

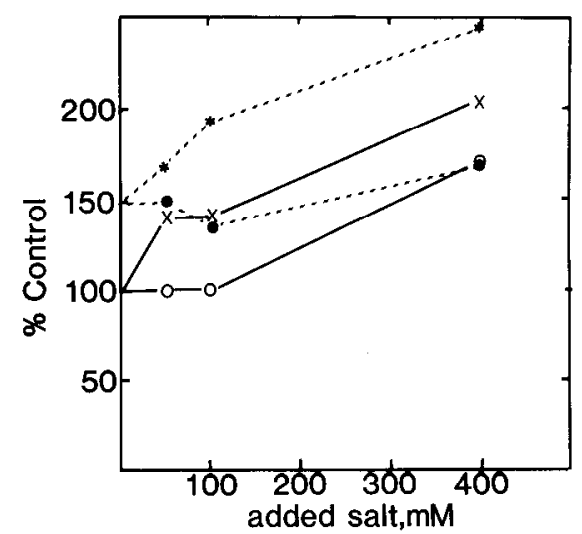

Figure 4. Effects of $\mathrm{NaCl}(O, \ominus)$ and $\mathrm{NH}_{4} \mathrm{Cl}\left(X,{ }^{*}\right)$ on $\left[{ }^{3} \mathrm{H}\right] \mathrm{DPX}$ binding to hippocampal membranes in the absence $(-)$ and presence $(---)$ of $100 \mu \mathrm{M} \mathrm{Gpp}(\mathrm{NH}) \mathrm{p}$. Points shown are averages of triplicate determinations. $\left[{ }^{3} \mathrm{H}\right] \mathrm{DPX}, 190 \mathrm{fmol} / \mathrm{mg}$ of protein, specifically bound when hippocampal membranes were incubated with $50 \mathrm{nM}\left[{ }^{3} \mathrm{H}\right] \mathrm{DPX}$ in the absence of $\mathrm{Gpp}(\mathrm{NH}) \mathrm{p}$ or added salt. All data are expressed as percentages of this value.

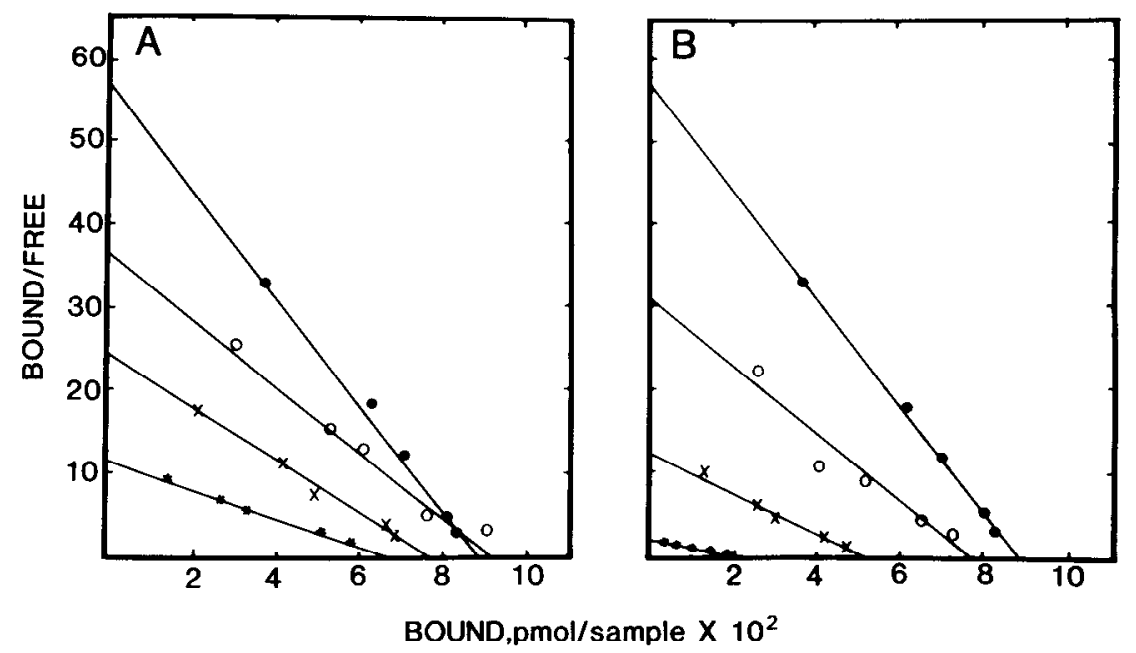

Figure 3. Scatchard plots of $\left[{ }^{3} \mathrm{H}\right]-$ L-PIA binding to hippocampal membranes in the presence of different concentrations of $\mathrm{NaCl}(A)$ and $\mathrm{NH}_{4} \mathrm{Cl}(B)$. The same control curve is shown in both panels as the entire experiment was performed in duplicate at the same time. Ordinate, Bound/Free (picomoles per sample $\cdot \mathrm{M}$ ) $\times 10^{-6}$. Abscissa, Bound, picomoles per sample $\times 10^{2}$. Control $(\odot), 200 \mathrm{mM}$ salt $(O), 400 \mathrm{mM}$ salt $(X)$, and 800 mM salt (*). The parameter estimates were as follows, $K_{D}$, nanomolar; $B_{\max }$ (femtomoles per milligram of protein): control, $1.5(827) ; 200 \mathrm{mM} \mathrm{NaCl}, 2.6(871) ; 400 \mathrm{mM} \mathrm{NaCl}, 3.1$ (720); $800 \mathrm{mM} \mathrm{NaCl}, 8.6(644) ; 200 \mathrm{mM} \mathrm{NH}_{4} \mathrm{Cl}, 2.4$ (708); $400 \mathrm{mM} \mathrm{NH} \mathrm{Cl}_{4}, 1.2$ (196); and $800 \mathrm{mM} \mathrm{NH}_{4} \mathrm{Cl}, 11.5$ (229). 


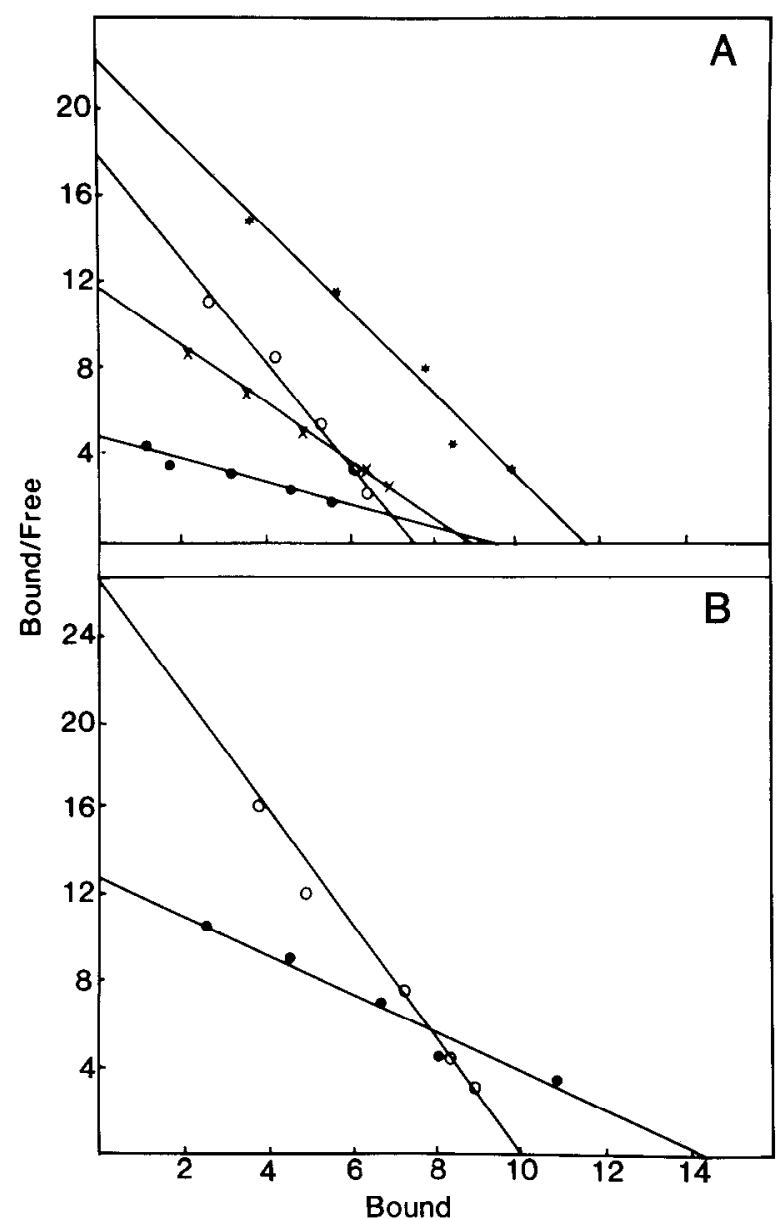

Figure 5. Scatchard plots of $\left[{ }^{3} \mathrm{H}\right] \mathrm{DPX}$ binding to control $(A)$ and NEM-pretreated $(B)$ hippocampal membranes. NEM-pretreated membranes were prepared as described by Yeung and Green (1983). Assays were performed in triplicate. Ordinate, Bound/Free, (femtomoles per sample . M) $\times 10^{-9}$. Abscissa, Bound, femtomoles per milligram of protein $\times 10^{-2}$. The parameter estimates were as follows: $K_{D}$, nanomolar; $B_{\max }$ (femtomoles per milligram of protein): control (O), $196(923)$; $400 \mathrm{mM} \mathrm{NH} \mathrm{NH}_{4} \mathrm{Cl}$ ), $40.5(742) ; 100 \mu \mathrm{M} \mathrm{Gpp}(\mathrm{NH}) \mathrm{p}(X), 60.9(867) ;$ $\mathrm{NH}_{4} \mathrm{Cl}+\mathrm{Gpp}(\mathrm{NH}) \mathrm{p}\left({ }^{*}\right), 52.6$ (1157); NEM pretreated (O), $110(1405) ;$ $\mathrm{NEM}$ pretreated $+\mathrm{NH}_{4} \mathrm{Cl}(\mathrm{O}), 37.1$ (997)

\section{TABLE II}

Effects of $\mathrm{NH}_{4} \mathrm{Cl}, \mathrm{Gpp}(\mathrm{NH}) \mathrm{p}$, and NEM pretreatment on ${ }^{3} \mathrm{HJDPX}$ binding to hippocampal membranes

All groups were studied in each preparation with the exception of the $\mathrm{NEM} / \mathrm{NH}_{4} \mathrm{Cl}$ group, which was studied in three of the four experiments. Values shown are means \pm SEM.

\begin{tabular}{lcc}
\hline \multicolumn{1}{c}{ Group } & $K_{D}$ & $B_{\max }$ \\
\hline & $n M$ & fmol/mg of protein \\
Control & $185.5 \pm 23.7$ & $696 \pm 183$ \\
$\mathrm{NH}_{4} \mathrm{Cl}, 0.4 \mathrm{M}$ & $66.4 \pm 23.9$ & $680 \pm 37$ \\
$\mathrm{Gpp}(\mathrm{NH}) \mathrm{p}, 100 \mu \mathrm{M}$ & $132.2 \pm 25.3$ & $1030 \pm 143$ \\
$\mathrm{NH}_{4} \mathrm{Cl}+\mathrm{Gpp}(\mathrm{NH}) \mathrm{p}$ & $68.1 \pm 13.6$ & $1012 \pm 64$ \\
$\mathrm{NEM}$ pretreated & $106.6 \pm 6.5$ & $1056 \pm 139$ \\
$\mathrm{NEM}$ pretreated $+\mathrm{NH}_{4} \mathrm{Cl}$ & $38.0 \pm 3.5$ & $853 \pm 75$ \\
\hline
\end{tabular}

monovalent cations. Thus, the difference between the results previously reported from this laboratory (Yeung and Green, 1983) and those reported by Goodman et al. (1982) appears to be due to the fact that in our previous study (Yeung and Green, 1983) incubations contained $\mathrm{NaCl}$ in the glycylglycine buffer employed. Therefore, we found that $\mathrm{Gpp}(\mathrm{NH}) \mathrm{p}$ both increased the $K_{D}$ for agonist binding and decreased the maximal number of sites to which the agonist bound (Yeung and Green, 1983), while Goodman et al. found that guanine nucleotides increased the $K_{D}$ for agonist binding without affecting the maximal number of sites to which the agonist bound. The present results suggest that $\left[{ }^{3} \mathrm{H}\right]$-L-PIA forms high affinity complexes with the $R_{i}$ receptors in the absence of added guanine nucleotide and that all of these complexes are converted to an intermediate affinity state in the presence of $\mathrm{Gpp}(\mathrm{NH}) \mathrm{p}$. In the presence of both $\mathrm{Gpp}(\mathrm{NH}) \mathrm{p}$ and $100 \mathrm{mM} \mathrm{NaCl}$ some of the binding to this intermediate affinity state remains, but some of the binding is converted to a lower affinity state that is not detected with the concentration range of $\left[{ }^{3} \mathrm{H}\right]-\mathrm{L}$-PIA studied. Higher concentrations of the monovalent cations themselves increase the $K_{D}$ and decrease the $B_{\max }$ of $\left[{ }^{3} \mathrm{H}\right]-\mathrm{L}-\mathrm{PIA}$. It is not possible to determine from the present experiments if the effects exerted by the lower concentrations of monovalent cations in the presence of $\mathrm{Gpp}(\mathrm{NH}) \mathrm{p}$ and those exerted by higher concentrations of the monovalent cations in the absence of added guanine nucleotide are mediated by the same monovalent cation site. In both cases $\mathrm{NH}_{4} \mathrm{Cl}$ is more potent than $\mathrm{NaCl}$. Hosey (1983) previously reported that $\mathrm{NH}_{4} \mathrm{Cl}$ is more potent than $\mathrm{NaCl}$ in modulating the binding of acetylcholine to cardiac muscarinic receptors. The different potencies of $\mathrm{NH}_{4} \mathrm{Cl}$ and $\mathrm{NaCl}$ in $\mathrm{Hos}-$ ey's and the present experiments are consistent with the assumption that these effects are due to the monovalent cations and not to the anions or nonspecific ionic effects.

In contrast to the effects of the monovalent cations on agonist binding, the binding of submaximal concentrations of the antagonist $\left[{ }^{3} \mathrm{H}\right] \mathrm{DPX}$ was increased in the presence of $\mathrm{NaCl}$ or $\mathrm{NH}_{4} \mathrm{Cl}$. Once more $\mathrm{NH}_{4} \mathrm{Cl}$ appeared to be more potent than $\mathrm{NaCl}$. This increased binding was attributable to a decrease in the $K_{D}$ rather than an increase in the $B_{\max }$. This effect of $\mathrm{NH}_{4} \mathrm{Cl}$ was the same in the absence and the presence of $\operatorname{Gpp}(\mathrm{NH}) \mathrm{p}$ and in NEM-pretreated membranes, suggesting that the effect on the monovalent cation does not involve the $N_{i}$ guanine nucleotide regulatory protein involved in the coupling of inhibitory receptors to adenylate cyclase (Cooper, 1982). It should also be noted that the effect of $\operatorname{Gpp}(\mathrm{NH}) \mathrm{p}$ to increase the $B_{\max }$ of $\left[{ }^{3} \mathrm{H}\right] \mathrm{DPX}$ was not affected by the presence of monovalent cation, unlike the situation with agonist binding in which the effect of $\mathrm{Gpp}(\mathrm{NH}) \mathrm{p}$ to decrease the $B_{\max }$ was enhanced by the presence of monovalent cation.

The present results are consistent with a model in which three affinity states for $R_{i}$ receptor:ligand complex exist such that $\mathrm{A} \rightleftharpoons \mathrm{B} \rightleftharpoons \mathrm{C}$. Assume that (1) state $\mathrm{A}$ has high agonistlow antagonist affinity, state $B$ has intermediate agonist and antagonist affinity, and state $C$ has low agonist-high antagonist affinity; (2) the agonist ligands $\left[{ }^{3} \mathrm{H}\right]-\mathrm{L}$-PIA and $\left[{ }^{3} \mathrm{H}\right] \mathrm{CHA}$ measure binding to $\mathrm{A}$ and $\mathrm{B}$ directly, while the antagonist ligand measures binding to $\mathrm{B}$ and $\mathrm{C}$ directly; and (3) guanine nucleotides modulate the transition between $\mathrm{A}$ and $\mathrm{B}$, while monovalent cations modulate the transition between $B$ and $C$. With regard to $\left[{ }^{3} \mathrm{H}\right]-\mathrm{L}-\mathrm{PIA}$ : (1) control-detect binding to $\mathrm{A}+\mathrm{B}$; (2) $+\mathrm{GPP}(\mathrm{NH}) \mathrm{p}-$ all $\mathrm{A} \rightarrow \mathrm{B}$, overall $K_{D} \uparrow, B_{\max } \rightarrow$; (3) monovalent cations - no effect, and (4) Gpp(NH)p + monovalent cation, $\mathrm{A} \rightarrow \mathrm{B}$ and some $\mathrm{B} \rightarrow \mathrm{C}, K_{D} \uparrow, B_{\max } \downarrow$. The latter decrease in $B_{\max }$ occurs because this low affinity agonist form of the receptor cannot be detected with L-PIA. With regard to $\left[{ }^{3} \mathrm{H}\right] \mathrm{DPX}$ : (1) controls - detect binding to B; (2) $\mathrm{Gpp}(\mathrm{NH}) \mathrm{p}$, $\mathrm{A} \rightarrow \mathrm{B}, K_{D} \rightarrow, B_{\max } \uparrow ;(3)+$ monovalent cation, $\mathrm{B} \rightarrow \mathrm{C}, K_{D} \downarrow$, $B_{\max } \rightarrow$; and (4) Gpp(NH)p + monovalent cation, $\mathrm{A} \rightarrow \mathrm{B} \rightarrow \mathrm{C}$, $K_{D} \downarrow, B_{\max } \uparrow$. According to this model the $\mathrm{R}_{\mathrm{i}}$ adenosine receptor exists in agonist-preferring and antagonist-preferring states, which suggests that alkylxanthines, such as DPX, inhibit the effects of $R_{\mathrm{i}}$ receptor agonists by an allosteric rather than by a competitive mechanism. The possible existence of agonistpreferring and antagonist-preferring states of receptors is im- 
plicit in the general discussion of cooperative models of drug action presented by Colquhoun (1973) and has been proposed for other specific receptor types, including opiate receptors (Pert and Snyder, 1974; Pasternak and Snyder, 1975) and dopamine receptors (Creese et al., 1965). The relationships between the three affinity states for agonist binding to $R_{i}$ receptors and the inhibition of adenylate cyclase activity are not yet clear. The finding that the inhibition of adenylate cyclase activity via $R_{i}$ receptors is dependent on the presence of guanine nucleotide (Londos et al., 1978; Cooper et al., 1980) and is amplified by monovalent cations (Cooper et al., 1980; Aktories et al., 1981) would suggest that state B or $\mathrm{C}$ must be formed to inhibit adenylate cyclase activity.

\section{References}

Aktories, K., G. Schultz, and K. H. Jakobs (1981) $\mathrm{Na}^{+}$amplifies adenosine receptor-mediated inhibition of adipocyte adenylate cyclase. Eur. J. Pharmacol. 71: 152-160.

Burgisser, E., A. DeLean, and R. J. Lefkowitz (1982) Reciprocal modulation of agonist and antagonist binding to muscarinic cholinergic receptor by guanine nucleotide. Proc. Natl. Acad. Sci. U. S. A. 79: 17321736.

Colquhoun, D. (1973) The relation between classical and cooperative models of drug action. In Drug Receptors, H. P. Rang, ed., pp. 149182, University Park Press, Baltimore.

Cooper, D. M. F. (1982) Biomodal regulation of adenylate cyclase. FEBS Lett. 138: 157-163.

Cooper, D. M. F., C. Londos, and M. Kodbell (1980) Adenosine receptor-mediated inhibition of rat cerebral cortical adenylate cyclase by a GTP-dependent process. Mol. Pharmacol. 18: 598-601.

Creese, I., D. R. Burt, and S. H. Snyder (1965) Dopamine receptor binding: Differentiation of agonist and antagonist states with ${ }^{3} \mathrm{H}$ dopamine and ${ }^{3} \mathrm{H}$ haloperidol. Life Sci. 17: 993-1002.

DeLean, A., B. F. Kilpatrick, and M. C. Caron (1982) Guanine nucleotides regulate both dopaminergic agonist and antagonist binding in porcine anterior pituitary. Endocrinology 110: 1061-1066.

Goodman, R. R., M. J. Cooper, M. Gavish, and S. H. Snyder (1982)
Guanine nucleotide and cation regulation of the binding of $\left[{ }^{3} \mathrm{H}\right]$ cyclohexyladenosine and $\left[{ }^{3} \mathrm{H}\right]$ diethylphenylxanthine to adenosine $\mathrm{A}_{1}$ receptors in brain membranes. Mol. Pharmacol. 21: 329-335.

Hosey, M. M. (1982) Regulation of antagonist binding to cardiac muscarinic receptors. Biochem. Biophys. Res. Commun. 107: 314321.

Hosey, M. M. (1983) Regulation of ligand binding to cardiac muscarinic receptors by ammonium ion and guanine nucleotides. Biochim. Biophys. Acta 751: 119-127.

Limbird, L. (1981) Activation and attenuation of adenylate cyclase. Biochem. J. 195: 1-13.

Londos, C., D. M. F. Cooper, W. Schlegel, and M. Rodbell (1978) Adenosine analogs inhibit adipocyte adenylate cyclase by a GTPdependent process: Basis for actions of adenosine and methylxanthines on cyclic AMP production and lipolysis. Proc. Natl. Acad. Sci. U. S. A. 75: 5362-5366.

Lowry, O. H., N. J. Rosebrough, A. L. Farr, and R. J. Randall (1951) Protein measurement with the Folin phenol reagent. J. Biol. Chem. 193: 265-275.

Pasternak, G. W., and S. H. Snyder (1975) Identification of novel high affinity opiate receptor binding in rat brain. Nature 253: 563-565.

Pert, C. B., and S. H. Snyder (1974) Opiate receptor binding of agonists and antagonists affected differentially by sodium. Mol. Pharmacol. 10: 868-879.

U'Prichard, D. C., J. C. Mitrius, D. J. Kahn, and B. D. Perry (1982) The $\alpha_{2}$-adrenergic receptor: Multiple affinity states and regulation of a receptor inversely coupled to adenylate cyclase. In Molecular Pharmacology of Neurotransmitter Receptor Systems, T. Sewaga, H. I. Yamamura, and K. Kuriyama, eds., pp. 53-72, Raven Press, New York.

Woodcock, E. A., and B. Murley (1982) Increased central $\alpha$-2 adrenergic receptors measured with $\left[{ }^{3} \mathrm{H}\right.$ ]yohimbine in the presence of sodium ion and guanylnucleotides. Biochem. Biophys. Res. Commun. 105: $252-258$.

Yeung, S.-M. H., and Green, R. D. (1983) Agonist and antagonist affinities for inhibitory adenosine receptors are reciprocally affected by 5 'guanylylimidodiphosphate or $N$-ethylmaleimide. J. Biol. Chem. 258: 2334-2339. 